\title{
Virulent Gene Characterization of Methicillin Sensitive Staphylococcus aureus (MSSA) and Methicillin Resistant Staphylococcus aureus (MRSA) from Bovine Mastitis
}

\author{
Hamid Shah ${ }^{1 *}$, Mohd Altaf Bhat ${ }^{1}$, Burhan Nabi ${ }^{2}$, \\ Anil Taku' and Gulzar Ahmed Badroo ${ }^{1}$ \\ ${ }^{1}$ Divison of Veterinary Microbiology and Immunology, F.V.Sc \& A.H., SKUAST-J, India \\ ${ }^{2}$ Division of Veterinary Medicine, F.V.Sc \& A.H, SKUAST-J, India \\ *Corresponding author
}

\begin{tabular}{l} 
K e y w o r d s \\
Amplification, \\
$\begin{array}{l}\text { Gene, Isolates, } \\
\text { Molecular, PCR, } \\
\text { Virulence }\end{array}$ \\
\hline Article Info \\
\hline $\begin{array}{l}\text { Accepted: } \\
\text { 26 May 2020 } \\
\text { Available Online: } \\
\text { 10 June 2020 }\end{array}$ \\
\hline
\end{tabular}

A B S T R A C T
The objective of the study was to characterize the virulence gene profile of MSSA and MRSA isolated from bovine mastitis. A total of 160 mastitic milk samples were collected from different regions of Jammu. Following different molecular techniques, a total of 36(37.5\%) isolates were confirmed as $S$. aureus. These $36 \mathrm{~S}$. aureus isolates were inoculated on ORSA to determine the phenotypic MRSA isolates. Only 20(55.5\%) isolates were confirmed to be MRSA phenotypically. All 36 isolates were subjected to mecA gene amplification by PCR. Only 6 isolates were mecA gene positive hence MRSA. Both MRSA and MSSA isolates were screened for virulence genes viz. coagulase $(c o a)$, staphylococcal protein $\mathrm{A}(\operatorname{spa})$, clumping factor (clfA), haemolysin $\mathrm{A}(h l a)$ and enterotoxins (eta \&etb). The coa gene was present in 35(97.2\%), spa in 35(97.2\%), clfA in 35(97.2\%), hla in 22(61.1\%) and eta \&etb in none of the isolates.

\section{Introduction}

Staphylococcus aureus present worldwide is a gram positive coccus, facultative anaerobe habitually positive for catalase and nitrate reduction and is coagulase variable which can be positive or negative. This organism can get transmitted from animals to humans through contamination of skin lesions while in contact with the affected animals, other possible vehicle including milkers hand and milking equipment is responsible for transmission of organism between animals. Due to its virulence factors like hyluronidase, protease, lipase, nuclease; coagulase; Clumping factors (Clf A); fibrinogen binding proteins (Fnbp A); Protein A; Panton-Valentine leucocidin (PVL); Staphylococcal Enterotoxin (SE) A to 
SEEand SEG to SEU; Exfoliative toxin (A \& B); Toxic shock syndrometoxin-1 (TSST-1); alpha and beta haemolysins, $S$. aureus exhibits wide range of diseases commonest of which is Mastitis thus deteriorating the milk quality (Gulzar et al., 2018, Hamid et al., 2017).Owing to mounting resistance to antibiotics, it is difficult to control virulent strains of $S$. aureus from causing mastitis posing greater threat to dairy industry (Hamid et al., 2017).

Soon after the resistance of $S$. aureus to penicillin antibiotic, in late 1950s $\beta$ lactamase resistant methicillin was introduced. However soon after introduction of Methicillin, the $S$. aureus developed resistance to it. Strains of $S$. aureus resistant to $\beta$-lactam antibiotics are known as methicillin-resistant $S$. aureus (MRSA) (Robinson and Enright, 2003). Methicillin resistance is caused by the acquisition of $m e c A$ gene. This produces an alternative penicillin binding protein $\mathrm{PBP} 2 \mathrm{a}$, which has lower affinity for $\beta$-lactam antibiotics (Vanderhaeghen et al., 2010). The $m e c A$ gene is a part of a large mobile genetic element, the staphylococcal cassette chromosome mec (SCCmec). Studies have shown that MRSA strains possess more toxin genes as compared to MSSA strains (Cai Youngwe et al., 2007). MRSA strains isolated from different geographical areas have shown to possess distinct toxin gene profiles (Cai Youngwe et al., 2007). The bovine MRSA may be transmitted to humans and may contribute to outbreaks in human populations (Lee, 2003). Therefore, monitoring the dissemination of virulence determinants and drug resistance genes among $S$. aureus isolates from bovine mastitis has become indispensable. The identification and characterization of virulence factors of $S$. aureus causing bovine mastitis will enhance our understanding of the pathogenesis of intra-mammary infection and may pave way for reduction in losses incurred to the dairy industry. Hence, this study was aimed for molecular characterization of virulent genes of $S$. aureus isolates obtained from mastitic milk of various dairy farms in Jammu.

\section{Materials and Methods}

\section{Sample collection}

This study was based on a total of 160 milk samples (80 cows and 80 buffaloes) collected from clinical as well as subclinical mastitis cases. Before sampling, the udders were inspected for externally observed pathological condition. Each milk sample was collected aseptically in a sterile screw-capped bottle from each mammary gland after washing with water and cleaning the teats with cotton soaked in $70 \%$ ethanol. The samples were immediately taken to the laboratory for bacteriological analysis. The various steps pertaining before characterizing the virulence genes are given in Diagram 1 and the sequence of the primers for PCR amplification specific to different genes of Staphylococcus aureus are given in Table 1.

\section{Molecular detection of virulence genes}

All the $S$. aureus isolates were screened for following virulence genes.

\section{Detection of coagulase (coa) gene}

The PCR amplification was performed in 25 $\mu \mathrm{l}$ in $0.2 \mathrm{ml}$ thin walled PCR tubes (Eppendorf, Germany). The PCR mixture contained a final concentration of $2.5 \mu \mathrm{l}$ of $10 \times$ coloured buffer, $3 \mathrm{mM} \mathrm{MgCl}_{2}, 1 \mu \mathrm{M}$ concentration of each primer (Table 1), 0.5 $\mathrm{mM}$ concentrations of each 2'deoxynucleoside 5'-triphosphate and 2U of Taq DNA polymerase (Promega, USA). The amplification cycles in Mastercycler Gradient Thermal cycler (Eppendorf, Germany) consisted of $94^{\circ} \mathrm{C}$ for $45 \mathrm{~s}$, followed by 30 
cycles of $94^{\circ} \mathrm{C}$ for $20 \mathrm{~s}, 57^{\circ} \mathrm{C}$ for $15 \mathrm{~s}$ and $70^{\circ} \mathrm{C}$ for $15 \mathrm{~s}$ and final extension at $72^{\circ} \mathrm{C}$ for 2min. Positive control DNA samples maintained in the laboratory were included in the PCR. Sterile distilled water was used as negative control.

\section{Detection of staphylococcal protein $\mathrm{A}(\mathrm{spa})$ gene}

The PCR amplification was performed in 25 $\mu \mathrm{l}$ in $0.2 \mathrm{ml}$ thin walled PCR tubes (Eppendorf, Germany) as per Montesinos et al., (2002). Positive control DNA samples maintained in the laboratory were included in the PCR. Sterile distilled water was used as negative control.

\section{Detection of clumping factor A(clfA)gene}

The PCR amplification was performed in 25 $\mu \mathrm{l}$ in $0.2 \mathrm{ml}$ thin walled PCR tubes (Eppendorf, Germany) as per Stephan et al., (2000). Positive control DNA samples maintained in the laboratory were included in the PCR. Sterile distilled water was used as negative control.

\section{Detection of staphylococcal enterotoxin genes (sea and seb)}

The PCR amplification was performed in 25 $\mu \mathrm{l}$ in $0.2 \mathrm{ml}$ thin walled PCR tubes (Eppendorf, Germany) as per Monday et al., (1999). Positive control DNA samples maintained in the laboratory were included in the PCR. Sterile distilled water was used as negative control.

\section{Detection of alpha- haemolysin(hla)}

The PCR amplification was performed in 25 $\mu \mathrm{l}$ in $0.2 \mathrm{ml}$ thin walled PCR tubes (Eppendorf, Germany) as per Booth et al., (2001). Positive control DNA samples maintained in the laboratory were included in the PCR. Sterile distilled water was used as negative control.

\section{Results and Discussion}

Results of the study have been presented below with suitable figures and tables wherever necessary isolates were inoculated on ORSA to determine the phenotypic MRSA isolates. Fromtotal 36 confirmed $S$. aureus isolates only $20(55.5 \%)$ isolates were confirmed to be MRSA phenotypically as shown in Fig. 1 and all 36 isolates were subjected to mecA gene amplification by PCRonly 6(16.6\%) isolates were confirmed to be methicillin resistant staphylococcus aureus (MRSA). The PCR product appeared as a single band with a size close to the expected size of $533 \mathrm{bp}$ as indicated in Fig. 2.

The relative distribution of all the studied virulence genes, in methicillin- resistant Staphylococcus aureus (MRSA) and methicillin-susceptible $S$. aureus (MSSA) isolates is depicted in Table 1.

Molecular detection of virulence genes coagulase gene (coa)

Out of 36 confirmed S. aureus, 35(97.2\%) amplified the coa gene specific product as depicted in Fig. 2. Out of 30 MSSA isolates, $29(96.6 \%)$ were coagulase positive strains and all MRSA isolates $6(100 \%)$ were coagulase positive. PCR amplified fragments as shown in Fig. 3.

For $S$. aureus the production of coagulase is considered as an important criterion for its identification and the detection of the gene responsible for coagulase production is often used for its characterization (Ahmadi et al., 2010). However, presence of coa (coagulase) gene is not species specific as $S$. aureus isolates deficient of this gene have also been confirmed (Kobayashi et al., 1995; Sanjiv et 
al., 2008). In our investigation, $100 \%$ and 96.6\% of isolates of MRSA and MSSA were coagulase positive respectively. This finding is in agreement with the report by (Kumar et al., 2011; Boerlin et al., 2003; Aarestrup et al., 1999) who also recounted $100 \%$ MRSA and $88.2 \%$ MSSA isolates coa gene positive.

\section{Staphylococcal protein A(spa) gene}

Out of 36 confirmed S. aureus, 35(97.2\%) were positive for Staphylococcal protein A and showed polymorphisim or variable PCR amplified fragments as shown in Fig. 4. Out of 30 MSSA isolates, 29(96.6\%) were spa gene positive whereas all MRSA isolates were positive for spa gene.

The spa gene is composed of functionally distinct regions, i.e. Fc binding region, $\mathrm{X}$ region and at $\mathrm{C}$-terminus. The $\mathrm{X}$-region of the spa gene includes a variable number of 24-bp repeats (Kuzma et al., 2003; Frenay et al., 1994) and because of this the spa genes have been the most widely used markers for molecular typing.

In our study, $100 \%$ of MRSA and $96.6 \%$ of MSSA isolates were spa gene positive which is in agreement with Marques et al., 2013 reported presence of spa gene in all of the isolates from bovine mastitis, showing variable amplicon sizes with 300 bp being the prevalent size.

Contrary to the results in the present study, uniform amplicons of $300 \mathrm{bp}$ size were obtained by Suleiman et al., 2012 in 20 isolates of $S$. aureus from subclinical bovine mastitis. The $S$. aureus isolates have also been reported to be spa gene-deficient by Shakeri et al., 2010. Enterotoxins of $S$. aureus play an important role in modulating the host immune response and contribute to maintain a suitable environment for its colonization (Omoe et al., 2003).

\section{Clumping factor ( clfA)gene}

Out of 36 confirmed S. aureus, 35(97.2\%) isolates were clumping factor(clfA) positive and showed a single amplicon with a size of approximately $980 \mathrm{bp}$ as shown in Fig. 5. All MRSA isolates carried $c l f A$ gene while as one MSSA isolate lacked $c l f A$ gene.

Clumping factor A ( $c l f A)$ gene is an important adhesion factor of $S$. aureus that facilitate its binding via soluble or immobilized fibrinogen. The clfA has also has the ability to inhibit phagocytosis by human PMNL which may explain its importance in $S$. aureus virulence in a variety of animal models of infection (Higgins et al., 2006). The screening of $S$. aureus isolates showed that the clfA gene was present in $100 \%$ and $99.6 \%$ of MRSA and MSSA isolates, respectively. Majority of the previous studies reported $100 \%$ correlation between clfA and coa gene in bovine $S$. aureus isolates (Akineden et al., 2001; Stephan et al., 2001; Salasia et al., 2004 and Reinoso et al., 2008) which is in concordance with our results.

\section{Alpha-haemolysin (hla) gene}

Out of 36 confirmed S. aureus, 22(61.1\%) were alpha haemolysin ( $h l a)$ positive and showed a single amplicon with a size of approximately $535 \mathrm{bp}$ as shown in Fig. 6. Among MSSA isolates, only 18 out of 30 $(60 \%)$ carried hla gene whereas only $4(66.6 \%)$ out of six MRSA isolates were positive for this gene.

Haemolysin is recognized as a potential virulence factor of $S$. aureus. According to Cifrian et al., 1996 interaction between alpha and beta haemolysin increases both adherence to bovine mammary epithelial cells and the proliferation of $S$. aureus. Haemolysin toxins include $\alpha$-, $\beta$ - and $\delta$-toxin act on cell membranes of RBC causing hemolysis (Table 2). 
Table.1 The sequence of the primers for PCR amplification specific to different genes of Staphylococcus aureus

\begin{tabular}{|c|c|c|c|}
\hline $\begin{array}{l}\text { Primer } \\
\text { name }\end{array}$ & Primer sequence $\left(5^{\prime}-3^{\prime}\right)$ & Reference & $\begin{array}{l}\text { Size } \\
\text { (bp) }\end{array}$ \\
\hline$n u c-1 \mathrm{~F}$ & GCGATTGATGGTGATACGGTT & \multirow[t]{2}{*}{ Louie et al., (2002) } & \multirow[t]{2}{*}{270} \\
\hline$n u c-2 \mathrm{R}$ & AGCCAAGCCTTGACGAACTAAAGC & & \\
\hline Staur 4 & ACGGAGTTACAAAGGACGAC & \multirow[t]{2}{*}{ Straub et al., (1999) } & \multirow[t]{2}{*}{1250} \\
\hline Staur 6 & AGCTCAGCCTTAACGAGTAC & & \\
\hline $\operatorname{mec} A \mathbf{F}$ & AAAATCGATGGTAAAGGTTGGC & \multirow[t]{2}{*}{ Louie et al., (2002) } & \multirow[t]{2}{*}{530} \\
\hline $\operatorname{mec} A \mathbf{R}$ & AGTTCTGCAGTACCGGATTTGC & & \\
\hline $\operatorname{coa} \mathbf{F}$ & ATAGAGATGCTGGTACAGG & \multirow[t]{2}{*}{ Hookey et al., (1998) } & \multirow[t]{2}{*}{ variable } \\
\hline $\operatorname{coa} \mathbf{R}$ & GCTTCCGATTGTTCGATGC & & \\
\hline spa $\mathbf{F}$ & TCAAGCACCAAAAGAGGAAGA & \multirow{2}{*}{$\begin{array}{l}\text { Montesinos et al., } \\
\quad \text { (2002) }\end{array}$} & \multirow[t]{2}{*}{ variable } \\
\hline spa $\mathbf{R}$ & GTTTAACGACATGTACTCCGTTG & & \\
\hline sea $\mathbf{F}$ & GCAGGGAACAGCTTTAGGC & \multirow[t]{4}{*}{ Monday et al., (1999) } & \multirow[t]{2}{*}{520} \\
\hline sea $\mathbf{R}$ & GTTCTGTAGAAGTATGAAACACG & & \\
\hline seb $\mathrm{F}$ & ACATGTAATTTTGATATTCGCACTG & & \multirow[t]{2}{*}{643} \\
\hline seb $\mathbf{R}$ & TGCAGGCATCATGTCATACCA & & \\
\hline hla $F$ & GGTTTAGCCTGGCCTTC & \multirow[t]{2}{*}{ Booth et al., (2001) } & \multirow[t]{2}{*}{535} \\
\hline hla $R$ & CATCACGAACTCGTTCG & & \\
\hline
\end{tabular}

Table.2 Absolute and relative distribution of staphylococcal virulence genes, coagulase (coa), staphylococcal protein A (spa), clumping factor (clfA), haemolysin ( $h l a)$ and enterotoxins (sea and seb) according to methicillin- resistant Staphylococcus aureus (MRSA) and methicillinsusceptible $S$. aureus isolate (MSSA)

\begin{tabular}{|l|c|c|c|}
\hline \multicolumn{1}{|c|}{ Gene } & $\begin{array}{c}\text { Total } \mathbf{n = 3 6} \\
\mathbf{n}(\boldsymbol{\%})\end{array}$ & $\begin{array}{c}\text { MSSA } \\
\mathbf{n = 3 0} \\
\mathbf{n}(\boldsymbol{\%})\end{array}$ & $\begin{array}{c}\text { MRSA } \\
\mathbf{n = 0 6} \\
\mathbf{n}(\boldsymbol{\%})\end{array}$ \\
\hline One or more & $35(97.22)$ & $29(96.60)$ & $6(100)$ \\
\hline coa & $35(97.22)$ & $29(96.6)$ & $6(100)$ \\
\hline spA & $35(97.22)$ & $29(96.6)$ & $6(100)$ \\
\hline clfA & $35(97.22)$ & $29(96.6)$ & $6(100)$ \\
\hline hla & $22(61.11)$ & $18(60)$ & $4(66.66)$ \\
\hline sea & 0 & 0 & 0 \\
\hline seb & 0 & 0 & 0 \\
\hline
\end{tabular}


Isolation of presumptive Staphylococcus aureus (Singh and Prakash, 2008)

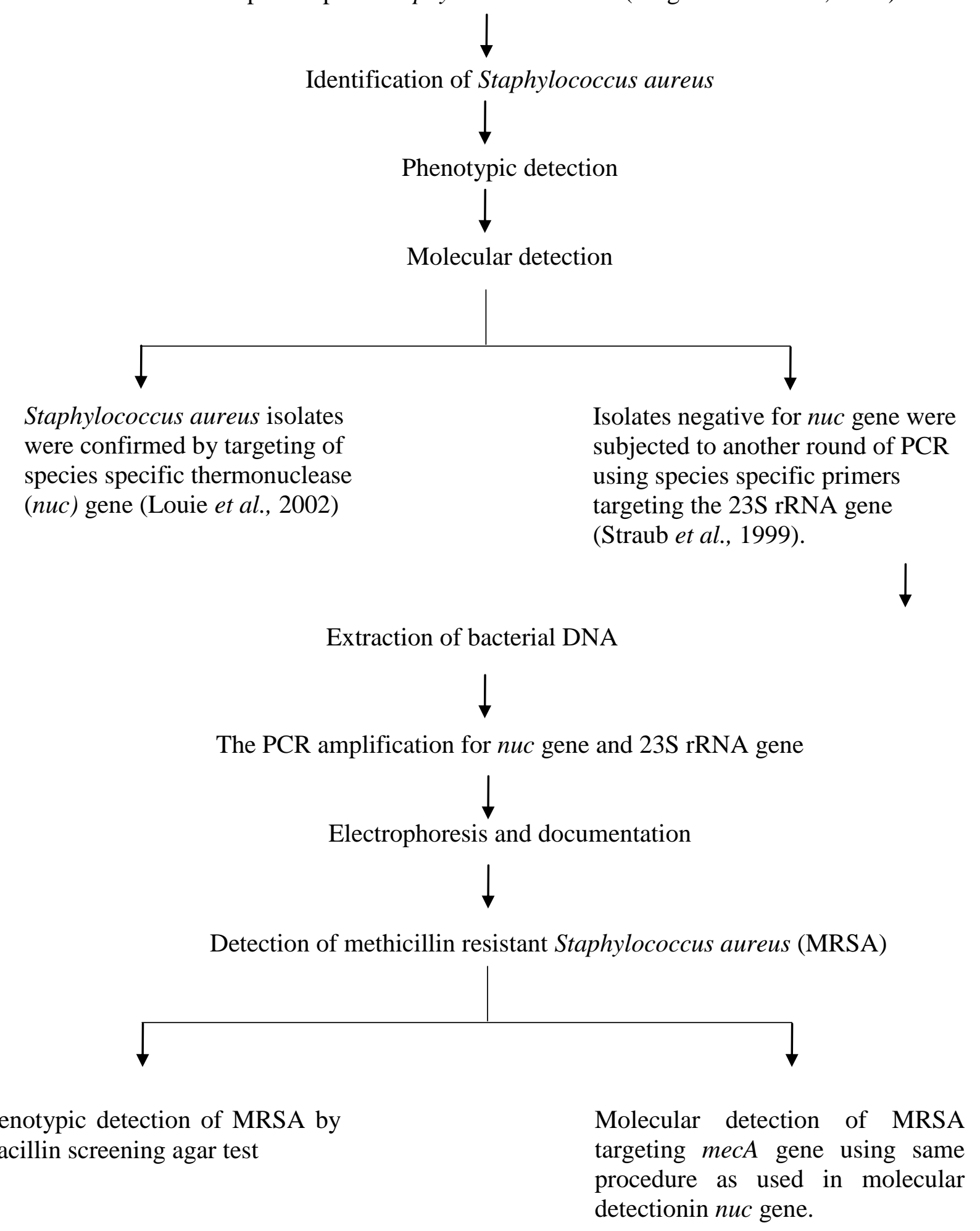

Phenotypic detection of MRSA by oxacillin screening agar test
Molecular detection of MRSA targeting mecA gene using same detectionin nuc gene.

Diagram.1 Steps pertaining before characterizing virulence genes 


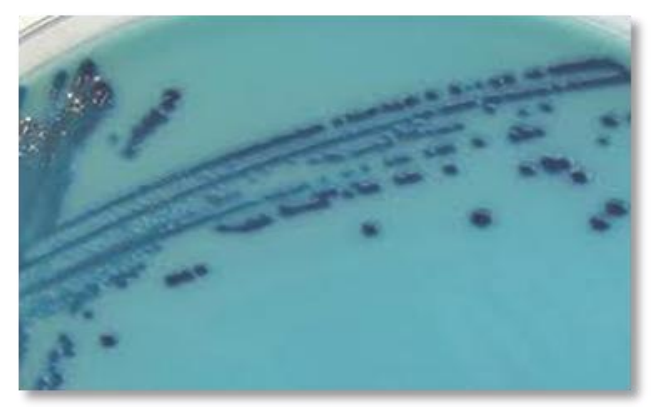

Fig.1 Typical blue colonies of $S$. aureus on ORSA agar showing phenotypic MRSA isolates

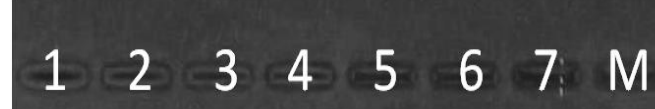

\section{Lane $\mathrm{M}$}

Lane 2,4,5

Lane 7

Lane 5,7-
Lane 2

Lane M

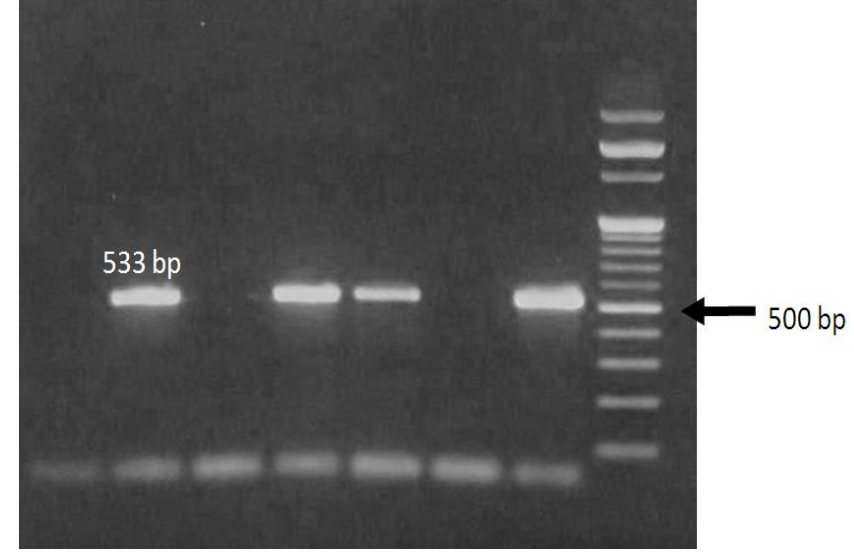

Fig.2 PCR amplification of MECA gene of S. aureus isolates - $\quad$ 100bp DNA ladder. Lane 1,3 - Negative isolates. - Positive isolates. Lane 6 - Negative control.

- Positive control.

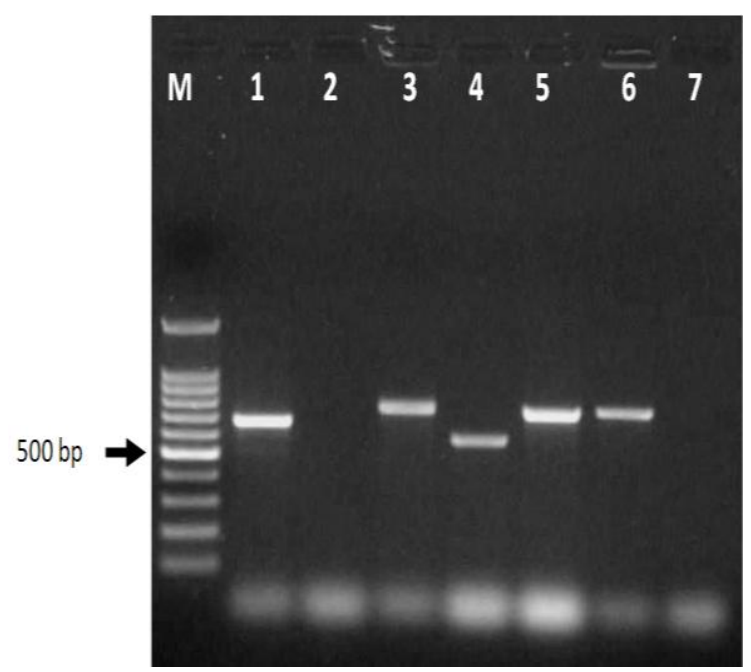

Fig.3 PCR amplification of coagulase gene (coa) of S. aureus isolates.

- 100 bp DNA ladder.

- Negative control. Negative isolate
Lane 1 - $\quad$ Positive control.

Lane 3,4,6 - $\quad$ Positive isolates. 


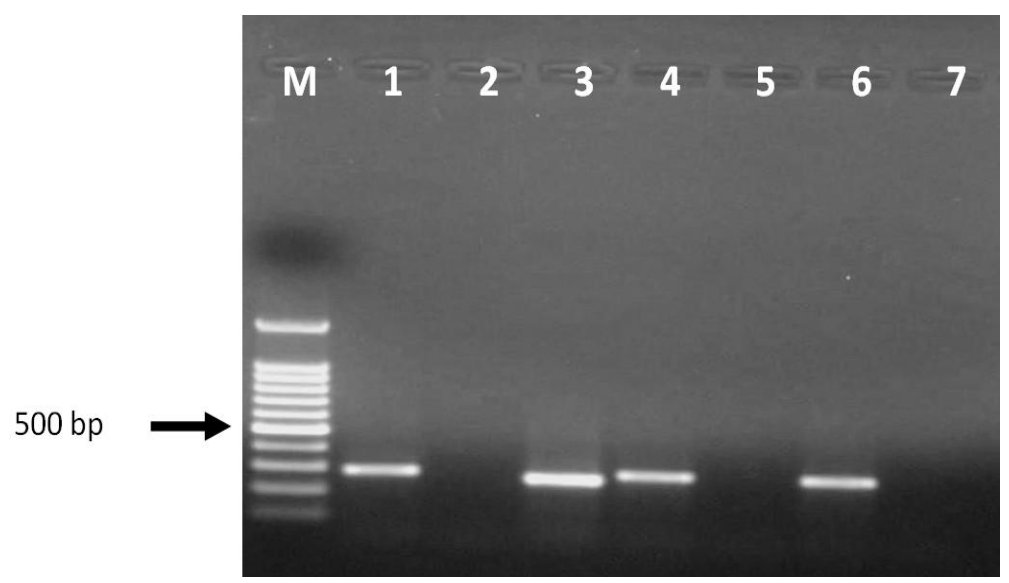

Fig.4 PCR Amplification of staphylococcal protein a gene(spa) of S. aureus Isolates

\section{Lane $\mathrm{M}$}

Lane 2

Lane 5,7-
- 100 bp DNA ladder.

- Negative control.

Negative isolate.

\section{Lane 1 - Positive control.}

Lane 3,4,6

- $\quad$ Positive isolates.

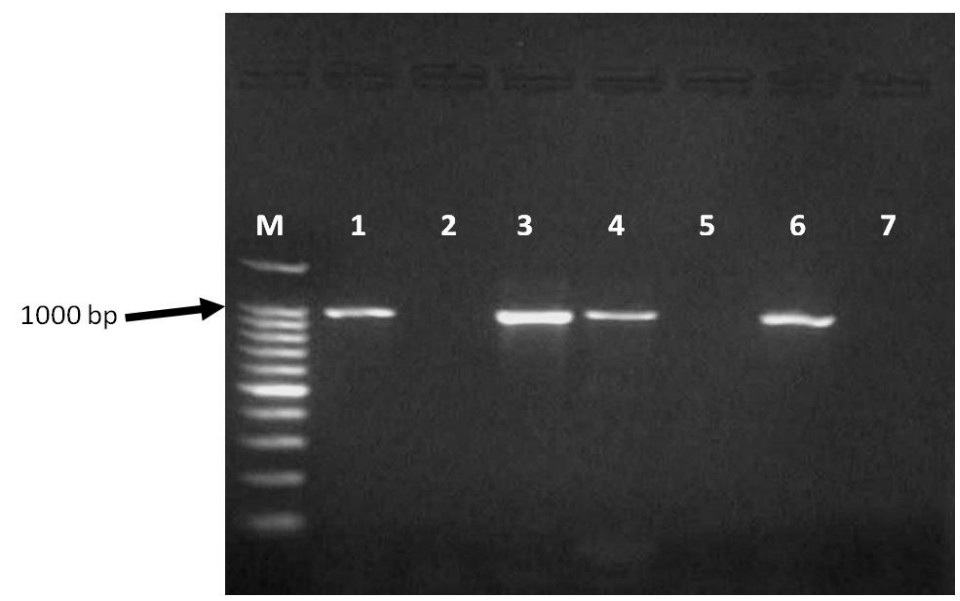

Fig.5 PCR amplification of clumping factor $(\mathrm{clfa})$ gene of $S$. aureus isolates

Lane $\mathrm{M}$

Lane 2

Lane 5,7-
Lane $\mathrm{M}$

Lane 2

Lane 5,7-
- 100 bp DNA ladder.

- Negative control.

Negative isolate
Lane 1 -

Lane 3,4,6
Positive control.

Positive isolates.

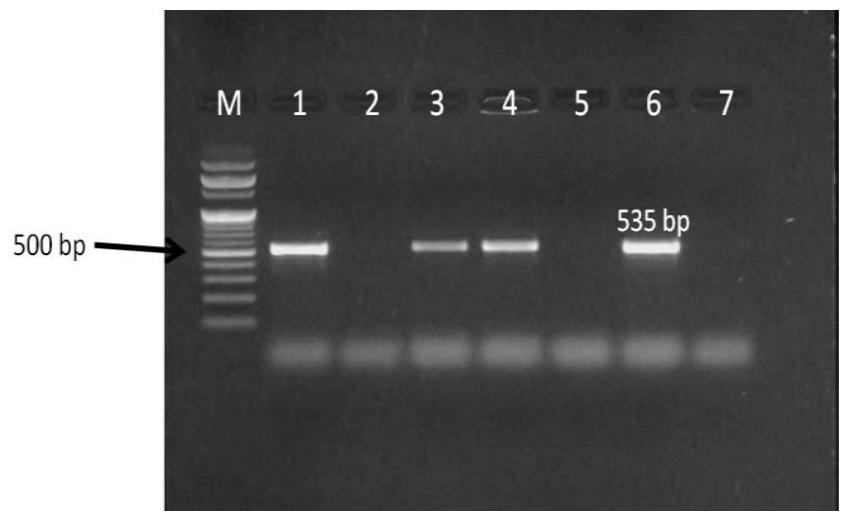

Fig.6 PCR amplification of alpha haemolysin (hla) gene of S. aureus isolates

- 100 bp DNA ladder.

- Negative control.

Negative isolate

\section{Lane 1 - Positive control.}

Lane 3,4,6 - $\quad$ Positive isolates. 
They can damage platelets, cause lysosome destruction, ischemia and necrosis of the body. In the present investigation, $66.6 \%$ of MRSA isolates and $60 \%$ of MSSA isolates were hla gene positive which is in contrast with Kumar et al., (2011) and Da Silva et al., (2005) as they found $100 \%$ and $85 \%$ of the isolates positive for hla gene. But our results are in agreement with Aarestrup et al., 1999 as he found $56 \%$ of the isolates $h l b$ gene positive. The remaining $S$. aureus isolates that were negative for hla may either have lost hla gene or the ability to express it or carried a variant gene and failed to express haemolytic activity in vitro as demonstrated by Aarestrup et al., 1999.

\section{Enterotoxin A and enterotoxin B(eta and etb)}

None of the $S$. aureus isolate carried either enterotoxin A (eta) or enterotoxin B (etb) gene. The main interest of studying enterotoxins, resides in their ability to cause food poisoning. The major enterotoxin gene present in mastitic $S$. aureus isolates include Sea-See, Seh, Seg, Sei, Sej,Seo and Tsst1(Stephan et al., 2001; Akineden et al., 2001, Zschöck et al., 2004).

In the present study, $S$. aureus isolates were screened for the presence of sea and seb but none of the isolates were positive for these enterotoxins. Previously, researchers have reported variability in the prevalence of enterotoxin genotypes among farms and countries (Akinedin et al., 2001; Gomez et al., 2007; Da Silva et al., 2005). The recovery of the enterotoxin genes in the present study was in agreement with the results of other studies (Oliveira et al., 2011; Fueyo et al., 2005). The possible reason may be that the researchers reported greater prevalence of newly enterotoxin genes ( $\mathrm{Seg}$ to $\mathrm{Seq}$ ), compared with classical enterotoxin genes (Sea to See).
The results of the present study may differ from previous investigations because of different clinical characteristics of mastitis or because more recently identified enterotoxins were not investigated. It is also possible that there is variability in the occurrence of enterotoxin genes among geographical regions.

\section{References}

Aarestrup, F.M., Lartsen, H.D., Eriksen, N.H., Elsberg, C.S. and Jensen N.E. 1999. Frequency of alpha and betahaemolysin in Staphylococcus aureus of bovine and human origin. A comparison between pheno- and genotype and variation in phenotypic expression. APMIS. 107: 425-430.

Ahmadi, M., Rohani, S.M.R. and Ayremlou, N. 2010. Detection of Staphylococcus aureus in milk by PCR. Comparative Clinical Pathology.19:91-94.

Akineden, O., Annemüller, C., Hassan, A. A., Lammler, C., Wolter, W. and Zschock, M. 2001. Toxin genes and other characteristics of Staphylococcus aureus isolates from milk of cows with mastitis. Clinical and Diagnostic Laboratory Immunology.8: 959-964.

Akineden, O., Annemüller, C., Hassan, A. A., Lammler, C., Wolter, W. and Zschock, M. 2001. Toxin genes and other characteristics of Staphylococcus aureus isolates from milk of cows with mastitis. Clinical and Diagnostic Laboratory Immunology.8: 959-964.

Boerlin, P., Kuhnert, P., Hüssy, D and Schaellibaum M. 2003. Methods for identification of Staphylococcus aureus isolates in cases of bovine mastitis. J. Clin. Microbiol. 41: 767-771.

Booth, M.C., Pence, L.M., Mahasreshti, P., Callegan, M.C., Gilmore, M.S. 2001. Clonal associations among Staphylococcus aureus isolates from 
various sites of infection. Infection and immunity. 69(1): 345-52.

Booth, M.C., Pence, L.M., Mahasreshti, P., Callegan, M.C., Gilmore, M.S. 2001. Clonal associations among Staphylococcus aureus isolates from various sites of infection. Infection and immunity.69(1): 345-52.

Cai Yongwe., Kong, F., Wang, Q., Tong, Z., Sintchenko, V., Zeng, X. 2007. Comparison of single- and multilocus sequence typing and toxin gene profiling for characterization of methicillin-resistant Staphylococcus aureus. Journal of Clinical Microbiology.45: 3302-8.

Cifrian, E., Guidry, A.J., Bramley, A.J., Norcross, N.L., Bastida- Corcuera, F.D. and Marquardt, W.W. 1996. Effect of staphylococcal beta toxin on the cytotoxicity, proliferation and adherence of Staphylococcus aureus to bovine mammary epithelial cells. Veterinary Microbiology.48: 187-198.

Da Silva, E.R., Boechat, J.U.D., Martins, J.C.D., Ferreira, W.P.B. Siqueira, A.P.S. and Da Silva, N., 2005. Hemolysin production by Staphylococcus aureus species isolated from mastitic goat milk in Brazilian dairy herds. Small Ruminant Research. 56: 271-275.

Da Silva, E.R., Boechat, J.U.D., Martins, J.C.D., Ferreira, W.P.B. Siqueira, A.P.S. and Da Silva, N. 2005. Hemolysin production by Staphylococcus aureus species isolated from mastitic goat milk in Brazilian dairy herds. Small Ruminant Research. 56: 271-275.

Frenay, H.M., Theelen, J.P., Schouls, L.M., Vandenbroucke- Grauls, C.M., Verhoef, J., van Leeuwen, W.J. and Mooi, F.R. 1994. Discrimination of epidemic and nonepidemic methicillin- resistant Staphylococcus aureus strains on the basis of Protein-A gene polymorphism. J. Clin. Microbiol. 32(3):846-847.

Fueyo, J. M., Mendoza, M. C., Rodicio, M. R., Muniz, J., Alvarez, M. A. and Martin, M. C. 2005. Cytotoxin and Pyrogenic Toxin Super antigen Gene Profiles of Staphylococcus aureus Associated with Subclinical Mastitis in Dairy Cows and Relationships with Macro restriction Genomic Profiles. Journal of Clinical Microbiology.43(3): 1278-1284.

Gómez, C., Pinal, L., Franco, J. et al., 2007 Identification of Staphylococcus aureus strains negative for enterotoxins A, B and $\mathrm{C}$ isolated from bovine mastitis in México. Vet Immunol Immunopathol. 117: 249-253.

Gulzar M., Zehra A. 2018. Staphylococcus aureus: A brief review. Int $\mathrm{J}$ Vet Sci Res. 4(1): 020-022.

Hamid S., Bhat M.A., Mir I.A., Taku A., Badroo G.A., Nazki S., Malik A. 2017. Phenotypic and genotypic characterization of methicillin-resistant Staphylococcus aureus from bovine mastitis. Veterinary World. 10(3): 363367.

Higgins, J., Loughman, A., Kessel, V.K.P., Strijp, V.J.A. and Foster, T.J. 2006. Clumping factor A of Staphylococcus aureus inhibits phagocytosis by human polymorphonuclear leucocytes. Federation of European Microbiological Societies Microbiology Letters.258(2): 290-296.

Hookey, J.V., Richardson, J.F. and Cookson, B.D. 1998. Molecular typing of Staphylococcus aureus based on PCR restriction fragment length polymorphism and DNA sequence analysis of the coagulase gene. Journal of Clinical Microbiology. 36(4): 10831089.

Kobayashi, N., Taniguchi, K., Kojima, K., Urasawa, S., Uehara, N., Omizu, Y., 
Kishi, Y., Yagihashi, A. and Kurokawa, I. 1995. Analysis of methicillin resistant and methicillin susceptible Staphylococcus aureus by a molecular typing method based on coagulase gene polymorphism. Epidemiology and Infection.115: 419-426.

Kumar, R., Yadav, B.R., Anand, S.K. and Singh, R.S. 2011. Molecular surveillance of putative virulence factors and antibiotic resistance in Staphylococcus aureus isolates recovered from intra-mammary infections of river buffaloes. Microbial Pathogenesis.51(1-2): 31-38.

Kuzma, K., Malinowski, E., Lassa, H. and Kłossowska, A. 2003. Specific detection of Staphylococcus aureus by PCR in intramammary infection. Bulletin of the Veterinary Institute in Pulawy.47: 183-190.

Lee, J.H. 2003. Methicillin (oxacillin)resistant Staphylococcus aureus strains isolated from major food animals and their potential transmission to humans. Applied and Environmental Microbiology.69: 6489-6494.

Louie, L., Goodfellow, J., Mathieu, P., Glatt, A., Louie, M. and Simor, A.E. 2002. Rapid Detection of MethicillinResistant Staphylococci from Blood Culture Bottles by Using a Multiplex PCR Assay. Journal of Clinical Microbiology. 2786-2790.

Marques, V.F., de Souza, M.M.S., de Mendonca, E.C.L., de Alencar, T.A., Pribul, B.R., Coelho, S.M.O. and Reinoso, M.L.E. 2013. Phenotypic and genotypic analysis of virulence in Staphylococcus spp. and its clonal dispersion as a contribution to the study of bovine mastitis. Pesqui. Vet. Brasil, 33(2):161-170.

Monday, S.R. and Bohach, G.A. 1999. Use of multiplex PCR to detect Classical and newly described pyrogenic toxin genes in Staphylococcal isolates. Journal of Clinical Microbiology.37: 3411-3414.

Monday, S.R. and Bohach, G.A. 1999. Use of multiplex PCR to detect Classical and newly described pyrogenic toxin genes in Staphylococcal isolates. Journal of Clinical Microbiology.37: 3411-3414.

Montesinos, I., Salido, E., Delgado, T., Cuervo, M. and Sierra, A. 2002. Epidemiological genotyping of Methicillin-Resistant Staphylococcus aureus by Pulsed Field Gel Electrophoresis at a University Hospital and comparison with Antibiotyping and Protein A and Coagulase gene Polymorphism. Journal of Clinical Microbiology. 40(6): 2119.

Oliveira, L. Rodrigues, A.C., Hulland, C. and Ruegg, P.L. 2011.Enterotoxin production, enterotoxin gene distribution, and genetic diversity of Staphylococcus aureus recovered from milk of cows with subclinical mastitis. American Journal of Veterinary Research. 72(10): 1361-1368.

Omoe, K., Hu, D.L., Takahashi-Omoe, H., Nakane, A. and Shinagawa, K. 2003. Identification and characterization of a new Staphylococcal enterotoxin-related putative toxin encoded by two kinds of plasmids. Infection and Immunity. 71: 6088-6094.

Reinosoa, E.B., El-Sayedb, A., Lammlerb, C., Bognia, C. and Zschockc, M. 2008. Genotyping of Staphylococcus aureus isolated from humans, bovine subclinical mastitis and food samples in Argentina. Microbiological Research. 163: 314-322.

Robinson, D.A., Enright, M.C. 2003. Evolutionary models of the emergence of methicillin resistant Staphylococcus aureus. Antimicrob. Agents Chemother. 47: 3926-3934.

Salasia, S.I.O., Khusnan, Z., Lammler, C. and Zschock, M. 2004. Studies on 
phenotypic and genotypic properties of Staphylococcus aureus isolated from bovine subclinical mastitis in central java in Indonesia and Hessen in Germany. Journal of Veterinary Science. 5(2): 103-109.

Sanjiv, K., Kataria, A.K., Sharma, R. and Singh, G. 2008. Epidemiological typing of Staphylococcus aureus by DNA restriction fragment length polymorphism of coa gene. Veterinarski Arhiv. 78(1): 31-38.

Shakeri, F., Shojai, A., Golalipour, M., Alang, S.R., Vaez, H. and Ghaemi, E.A. 2010. Spa diversity among MRSA and MSSA strains of Staphylococcus aureus in north of Iran. Int. J. Microbiol, 2010: 351-397.

Singh, P. and Prakash, A. 2008. Isolation of Escherichia coli, Staphylococcus aureus and Listeria monocytogenes from milk products sold under market conditions at Agra Region. Acta Agri. Slov. 92(1): 83-88.

Stephan R., Annemuller, C. Hassan, A.A and Lammler, Ch. 2001. Characterization of enterotoxigenic Staphylococcus aureus strains isolated from bovine mastitis in north-east Switzerland. Veterinary Microbiology. 78: 373-382.

Stephan, R., Senczek, D. and Dorigon, V. 2001. Enterotoxin production and other characteristics of Staphylococcus aureus strains isolated from human nasal carriers. Arch Lebensmittelhyg.52: 7-9

Stephan, R., Senczek, D. and Dorigon, V. 2001. Enterotoxin production and other characteristics of Staphylococcus aureus strains isolated from human nasal carriers. Arch Lebensmittelhyg. 52: 7-9.

Straub, J.A., Hertel, C. and Hammes, W.P. 1999. A 23S rRNA-targeted polymerase chain reaction based system for detection of Staphylococcus aureus in meat starter cultures and dairy products. J. Food. Prot.62:1150-1156.

Suleiman, A.B., Kwaga, J.K.P., Umoh, V.J., Okolocha, E.C., Muhammed, M., Lammler, C., Shaibu, S.J., Akineden, O. and Weiss, R. 2012. Macro-restriction analysis of Staphylococcus aureus isolated from subclinical bovine mastitis in Nigeria. Afr. J. Microbiol Res. 6(33): 6270-6274.

Vanderhaeghen, W., Cerpentier, T., Adriaensen, C., Vicca, J., Hermans, K., Butaye, P. 2010. MRSA ST398 associated with clinical and subclinical mastitis in Belgian. Vet Microbiol. 144(1-2): 166- 171.

Zschock, M., Risse, K. and Sommerhauser, J. 2004. Occurrence and clonal relatedness of sec/tst-gene positive Staphylococcus aureus isolates of quarter milk samples of cows suffering from mastitis. Letters in Applied Microbiology. 38(6): 493 498.

\section{How to cite this article:}

Hamid Shah, Mohd Altaf Bhat, Burhan Nabi, Anil Taku and Gulzar Ahmed Badroo. 2020. Virulent Gene Characterization of Methicillin Sensitive Staphylococcus aureus (MSSA) and Methicillin Resistant Staphylococcus aureus (MRSA) from Bovine Mastitis. Int.J.Curr.Microbiol.App.Sci. 9(06): 3471-3482. doi: https://doi.org/10.20546/ijcmas.2020.906.409 